I nt er l euki n- 6 upr egul at es the expressi on of PMP22 in cul tured $r$ at Schwann cell s vi a a JAK2- dependent pat hway

\begin{tabular}{|l|l|}
\hline 著者 & $\begin{array}{l}\text { I t o Takaaki, I keda Kazuo, Tom t a Kat sur o, } \\
\text { Yokoyana Shi ger u }\end{array}$ \\
\hline $\begin{array}{l}\text { j our nal or } \\
\text { publ i cat i on ti t l e }\end{array}$ & Neur osci ence Let ter s \\
\hline vol une & 472 \\
\hline number & 2 \\
\hline page r ange & 104108 \\
\hline year & $2010-0319$ \\
\hline URL & ht t p: //hdl . handl e. net /2297/21587 \\
\hline
\end{tabular}




\section{Elsevier Editorial System(tm) for Neuroscience Letters Manuscript Draft}

Manuscript Number: NSL-09-2014R1

Title: Interleukin-6 upregulates the expression of PMP22 in cultured rat Schwann cells via a JAK2dependent pathway

Article Type: Research Paper

Keywords: interleukin-6; peripheral myelin protein 22; gp130; JAK2; STAT3; Schwann cell

Corresponding Author: Dr. Shigeru Yokoyama, M.D., Ph.D.

Corresponding Author's Institution: Kanazawa University Graduate School of Medicine

First Author: Takaaki Ito, M.D.

Order of Authors: Takaaki Ito, M.D.; Kazuo Ikeda, M.D.,Ph.D.; Katsuro Tomita, M.D.,Ph.D.; Shigeru Yokoyama, M.D., Ph.D.

Abstract: The interleukin-6 (IL-6) family of cytokines is thought to be involved in the development and regeneration of peripheral nerves; however, their roles in myelination remain unclear. In this study, we examined the effects of IL-6 on the expression of genes for compact myelin proteins using Schwann cell cultures prepared by multiple explantation of adult rat sciatic nerves. In semi-quantitative reverse transcription-polymerase chain reaction analysis, stimulation of Schwann cells with IL-6 significantly increased the mRNA level of peripheral myelin protein 22 (PMP22), but not those of myelin protein zero and myelin basic protein. The increase in PMP22 mRNA was markedly suppressed by AG490, a Janus kinase 2 (JAK2) inhibitor, but not significantly by PD098059, a mitogen-activated protein kinase kinase inhibitor. Immunocytochemical staining revealed that IL- 6 enhanced immunoreactivities for the phosphorylated forms of both JAK2 and signal transducer and activator of transcription 3 (STAT3), as well as that for PMP22. These results indicate that IL- 6 can enhance PMP22 production in Schwann cells via a JAK2-dependent pathway by probably activating STAT3 and thus may contribute to myelination. 


\title{
Interleukin-6 upregulates the expression of PMP22 in cultured rat Schwann cells via a JAK2-dependent pathway
}

\author{
Takaaki Ito $^{\text {a, b }}$, Kazuo Ikeda ${ }^{\text {a }}$, Katsuro Tomita ${ }^{\text {a }}$, Shigeru Yokoyama ${ }^{\text {b, } *}$ \\ a Department of Orthopaedic Surgery, School of Medicine, Kanazawa University, 13-1
}

Takara-machi, Kanazawa 920-8641, Japan

${ }^{\mathrm{b}}$ Department of Biophysical Genetics, Kanazawa University Graduate School of Medicine,

13-1 Takara-machi, Kanazawa 920-8640, Japan

Total 23 pages (3656 words)

1 table

4 figures

* Corresponding author at: Department of Biophysical Genetics, 13-1 Takara-machi,

Kanazawa 920-8640, Japan.

Tel: +81 76265 2457; fax: +81234 4236 .

E-mail address: shigeruy@med.kanazawa-u.ac.jp (S. Yokoyama). 


\section{ABSTRACT}

The interleukin-6 (IL-6) family of cytokines is thought to be involved in the development and regeneration of peripheral nerves; however, their roles in myelination remain unclear. In this study, we examined the effects of IL-6 on the expression of genes for compact myelin proteins using Schwann cell cultures prepared by multiple explantation of adult rat sciatic nerves. In semi-quantitative reverse transcription-polymerase chain reaction analysis, stimulation of Schwann cells with IL-6 significantly increased the mRNA level of peripheral myelin protein 22 (PMP22), but not those of myelin protein zero and myelin basic protein. The increase in PMP22 mRNA was markedly suppressed by AG490, a Janus kinase 2 (JAK2) inhibitor, but not significantly by PD098059, a mitogen-activated protein kinase kinase inhibitor. Immunocytochemical staining revealed that IL-6 enhanced immunoreactivities for the phosphorylated forms of both JAK2 and signal transducer and activator of transcription 3 (STAT3), as well as that for PMP22. These results indicate that IL-6 can enhance PMP22 production in Schwann cells via a JAK2-dependent pathway by probably activating STAT3 and thus may contribute to myelination.

Key words: interleukin-6, peripheral myelin protein 22, gp130, JAK2, STAT3, Schwann cell 
Myelin synthesis by Schwann cells is an important process in the regeneration of injured peripheral nerves as well as in the normal development of the peripheral nervous system (PNS) $[4,9,12]$. It is well known that myelination by Schwann is regulated by various endogenous modulators including extracellular matrix proteins, neurotrophic factors, and cytokines $[3,4]$. Of these, interleukin-6 (IL-6) and its related cytokines, such as ciliary neurotrophic factor, leukemia inhibitory factor, and interleukin-11, are particularly important, because mice depleted of the glycoprotein-130 (gp130) gene, which encodes a common receptor subunit for these cytokines, exhibit degeneration of peripheral myelin sheath [2]. As already established in non-neuronal tissues, the IL-6 family of cytokines exert their effects through the Janus kinase/signal transducer and activator of transcription (JAK/STAT) and RAS/mitogen-activated kinase (RAS/MAPK) pathways [6,11]. The balance or interplay of these pathways is thought to determine the cell type-specific responses [6,11]. Although receptor subunits specific for these cytokines and gp130 are expressed in Schwann cells $[10,13,20]$, very little is known about their downstream effector molecules [14,28].

IL-6 is involved in various pathophysiological processes in the PNS [8,29]. Several studies have demonstrated that the expression of IL-6 and IL-6 receptor $\alpha$ subunit (IL-6R $\alpha$ ) is upregulated in dorsal root ganglion (DRG) neurons after axonal injury and elongation $[8,13,17,19,22,26]$. However, the biological actions of IL-6-signaling on Schwann cells have not fully been elucidated. We previously found out that IL-6 increased mRNA level of 
peripheral myelin protein 22 (PMP22) in cultured rat Schwann cells [19]. To further clarify the role of IL- 6 in the peripheral myelin synthesis, we examined the effects of IL-6 on other myelin-associated proteins and gp130-mediated signaling pathways using cultured Schwann cells.

Schwann cells were cultured from rat sciatic nerves by the multiple explantation method as described previously [16,19]. Adult male Wistar rats (150-200 g; Charles River Japan, Yokohama, Japan) were decapitated after deep anesthesia with diethyl ether and chloral hydrate (500 mg/kg, intraperitoneally), and sciatic nerves were dissected. Connective tissue, blood vessels, and epineurium were removed in Hanks' balanced salt solution using fine forceps. The nerves were then cut into approximately $1 \times 1-\mathrm{mm}$ pieces, which were placed on 35-mm tissue culture plastic dishes. All experiments were performed according to the Guidelines for the Care and Use of Laboratory Animals in Kanazawa University. The resulting explants were cultured in Dulbecco's Modified Eagle's Medium (DMEM; Invitrogen, Carlsbad, CA) supplemented with $10 \%$ fetal calf serum (FCS), $100 \mathrm{U} / \mathrm{ml}$ penicillin and $100 \mu \mathrm{g} / \mathrm{ml}$ streptomycin at $37^{\circ} \mathrm{C}$ in a humidified incubator containing $5 \%$ $\mathrm{CO}_{2}$. Fibroblast cells were depleted by transferring the explants using fine forceps to new dishes every week. After repeating this procedure 4-5 times, cells that migrated out of the explants were replated on poly-L-lysine-coated 60-mm dishes, and expanded in DMEM containing $10 \%$ FCS, $20 \mu \mathrm{g} / \mathrm{ml}$ bovine pituitary extract (KURABO, Osaka, Japan) and $2 \mu \mathrm{M}$ 
forskolin (Sigma, St.Louis, MO).

The purity of Schwann cells were assessed by immunocytochemical staining for S100 calcium-binding protein (S100) as follows. After removing the medium, cells were sequentially incubated in (1) 4\% paraformaldehyde (PFA); (2) phosphate-buffered saline (PBS), 2 changes, 5 min each; (3) blocking solution (PBS containing 0.3\% Triton X-100, 1\% bovine serum albumin, and $1 \%$ normal goat serum), 30 min at $4{ }^{\circ} \mathrm{C}$; (4) mouse monoclonal anti-rat S100 antibody (1:500; Sigma) in the blocking solution, overnight at $4{ }^{\circ} \mathrm{C}$; (5) PBS containing $0.3 \%$ Triton X-100, 5 changes, 5 min each; (6) biotinylated goat-anti rabbit IgG (1:2000; Amersham Biosciences, Piscataway, NJ) in the blocking solution, $3 \mathrm{~h}$ at room temperature; (7) PBS containing 0.3\% Triton X-100, 5 changes, 5 min each; (8) ExtrAvidin-Peroxidase (1:1000; Sigma), $1 \mathrm{~h}$ at room temperature; (9) PBS containing 0.3\% Triton X-100, 5 changes, 5 min each; and (10) 3, 3'-diaminobenzidine $(0.5 \mathrm{mg} / \mathrm{ml}$; Sigma)/0.015\% $\mathrm{H}_{2} \mathrm{O}_{2}$ in $50 \mathrm{mM}$ Tris- $\mathrm{HCl}, \mathrm{pH} 7.5$. Cells were observed under a light microscope (IX71; Olympus, Tokyo, Japan), and digital images were acquired using a computer-linked camera (DP71; Olympus).

Schwann cells were treated with recombinant rat IL-6 (PeproTech, Rocky Hill, NJ) at a concentration of $0.1,0.5$, and $1.0 \mu \mathrm{g} / \mathrm{ml}$. After $12-48 \mathrm{~h}$, the cells were harvested for further analyses. In some experiments, the cells were pretreated with the JAK2-specific inhibitor AG490 [15] (50 $\mu \mathrm{M}$; Calbiochem, La Jolla, CA) for $16 \mathrm{~h}$, or with the MAPK kinase 
(MAPKK)-specific inhibitor PD098059 [5] (25 $\mu \mathrm{M}$; Calbiochem) for $30 \mathrm{~min}$ before treatment with recombinant rat IL-6 $(0.5 \mu \mathrm{g} / \mathrm{ml})$ for $12 \mathrm{~h}$, as described in $[5,15]$.

The expression of IL-6R $\alpha$, gp130, myelin protein zero (MPZ), myelin basic protein (MBP), PMP22, and cyclophilin (CYC) was analyzed by reverse transcription (RT)-polymerase chain reaction (PCR) as previously described [19]. The primer sequences, annealing temperatures, and expected product sizes are given in Table 1.

The reaction products were electrophoresed through a $1.5 \%$ agarose gel, and were visualized by staining with ethidium bromide. The amplified cDNAs for IL-6R $\alpha$, gp130, MPZ, MBP, PMP22, and CYC were further cloned into a pCR2.1-TOPO vector (Invitrogen) to yield pCIL6R, pCGP130, pCMPZ, pCMBP, pCPMP22, and pCCYC, respectively; the cDNA inserts were verified by nucleotide sequencing. In addition to ethidium bromide-staining, the PCR products were confirmed by Southern blot hybridization analysis as described previously [19]. The probes used were the 250-bp HinfI (87)/BamHI (338) fragment from pCIL6-R, 200-bp FokI (155)/FokI (358) fragment from pCGP130, 310-bp ClaI (298)/PstI (604) fragment from pCMPZ, 330-bp StuI (31)/StuI(358) fragment from pCMBP, 360-bp BamHI (228)/HincII (586) fragment from pCPMP22, and 200-bp AluI (22)/FokI (218) fragment from pCCYC labeled by the random priming method; numbers in parentheses are in accordance with the GenBank database (accession number NM_017020 for rat IL-6R $\alpha$, M92340 for rat gp130, K03242 for rat MPZ, NM_017026 for rat MBP, 
NM_017037 for rat PMP22, and M19533 for rat CYC), and represent the 5'-terminal nucleotide generated by restriction endonuclease cleavage. Autoradiography was carried out at room temperature using an intensifying screen. Band intensities were quantified by densitometric scanning using the Scion Image program (Sion Corp., Frederick, MD), and were normalized to those for CYC mRNA. All data are expressed as the mean \pm standard error of the mean (SEM). Data from several conditions were compared by unpaired Student's $t$ test. $p$ values less than 0.05 were considered statistically significant.

Immunoperoxidase staining for IL-6R subunits and myelin-associated proteins was performed as described above for S100 protein, except that cells were permeabilized with $100 \%$ methanol at $-20{ }^{\circ} \mathrm{C}$ for 10 min after fixation with $4 \%$ PFA. Primary antibodies used were goat anti-PMP22 (1: 50; Santa Cruz Biotechnology, Santa Cruz, CA), rabbit anti-phospho-JAK2 (pJAK2; Tyr1007/1008; 1:100; Cell Signaling Technology, Beverly, MA), rabbit anti-phospho-STAT3 (pSTAT3; Tyr 705; 1:100; Cell Signaling Technology) antibodies. Secondary antibodies used were biotinylated rabbit anti-goat IgG (1: 2000; Amersham Biosciences) for PMP22, and biotinylated goat-anti rabbit IgG (1:2000; Amersham Biosciences) for pJAK2 and pSTAT3.

Figure1A shows Schwann cells purified from adult rat sciatic nerve. At least $98 \%$ of the cells were positive for S100, a Schwann cell-specific marker [12]. RT-PCR analysis of total cellular RNA indicated that the mRNAs for IL-6R and gp130 were present in these cells (Fig. 
1B).

Using this Schwann cell culture, we examined the effects of IL-6 on mRNA levels for MPZ, MBP, and PMP22 by RT-PCR combined with Southern blot hybridization. Relative intensities for MPZ mRNA levels were $0.50 \pm 0.35(n=3), 0.80 \pm 0.23(n=3)$, and $0.57 \pm$ $0.56(n=3)$, when IL-6 was added at concentrations of $0.1,0.5$, and $1.0 \mu \mathrm{g} / \mathrm{ml}$, respectively; these values were not significantly high compared with that obtained in the absence of IL-6 $(0.49 \pm 0.42, n=3 ; p>0.05$; Fig. $2 \mathrm{~A}$ and B). The intensities for MBP mRNA were also not significantly changed ( $p>0.05$; Fig. $2 \mathrm{~A}$ and B); the values were $1.10 \pm 0.71(n=3)$ in the absence of IL-6; $0.48 \pm 0.23(n=3)$ at $0.1 \mu \mathrm{g} / \mathrm{ml} ; 1.01 \pm 0.57(n=3)$ at $0.5 \mu \mathrm{g} / \mathrm{ml}$; and 0.78 $\pm 0.49(n=3)$ at $1.0 \mu \mathrm{g} / \mathrm{ml}$. In contrast, PMP22 mRNA levels were significantly elevated at 0.5 and $1.0 \mu \mathrm{g} / \mathrm{ml}(1.56 \pm 0.75, n=8$; and $1.74 \pm 1.01, n=8$, respectively) compared with those cells cultured without IL-6 $(0.61 \pm 0.14, n=8 ; p<0.05$; Fig. 2A and B). These results confirm the previous data obtained by utilizing glyceraldehyde-3-phosphate dehydrogenase as an internal control [19], and indicates that IL-6 preferentially acts on PMP22 expression.

We next examined intracellular signaling pathway(s) involved in the elevation of PMP22 mRNA by pretreating Schwann cells with a JAK2 or MAPKK inhibitor. As shown in Fig. 3A and B, pretreatment with $50 \mu \mathrm{M}$ AG490 significantly inhibited the increase in PMP22 mRNA $(0.02 \pm 0.004, n=10)$ compared with the intensities obtained without pretreatment $(0.82 \pm 0.16, n=5$; IL-6 at $0.5 \mu \mathrm{g} / \mathrm{ml} ; p<0.05)$; the level was almost the same 
as that in the absence of IL-6 $(0.13 \pm 0.08, n=5)$. In contrast, pretreatment with $25 \mu \mathrm{M}$ PD098059 did not show significant inhibition $(0.54 \pm 0.19, n=10 ; p>0.05)$. These data indicated that IL-6 upregulated PMP22 mRNA mainly through the activation of JAK/STAT pathway.

To confirm the above findings, we performed immnocytochemical staining. As shown in Fig. 4A and B, addition of IL-6 enhanced PMP22-immunoreactivity (IR) in Schwann cells. IR for pJAK2, an active form of JAK2, was barely detectable in cells cultured without IL-6 (Fig. 4C), but was prominent in cells stimulated with IL-6 (Fig. 4D). In addition, IR for pSTAT3, an active form of STAT3, was steadily detected in the nucleus of IL-6-treated cells, but only weakly in untreated cells (Fig. 4E and F), indicating that IL-6 activated the JAK2/STAT3 signaling pathway in Schwann cells.

The present study in cultured rat Schwann cells has shown that IL-6 elevates the mRNA level of PMP22 but not those of MPZ and MBP, and that the increase in PMP22 mRNA is JAK2 inhibitor-sensitive and accompanied by phosphorylation of JAK2 and STAT3. These results suggest the involvement of the JAK/STAT pathway in PMP22 expression.

PMP22 is a tetraspan glycoprotein vigorously produced by myelinating Schwann cells $[9,18,24,25]$. Despite its abundant presence in the compact myelin, the physiological role of PMP22 has not been fully clarified. In good correlation with myelin formation, PMP22 expression in sciatic nerve is strongly upregulated during the postnatal period $[9,18,24,25]$ 
and during nerve regeneration after injury $[9,24,25]$. Duplication of the PMP22 genes is associated with hereditary demyelinating neuropathies, such as Charcot-Marie-Tooth disease type $1 \mathrm{~A}$, and deletion of a single gene copy leads to hereditary neuropathy with liability to pressure palsies [25]. Amici et al. (2006) recently demonstrated that PMP22 exists in a complex with $\alpha 6 \beta 4$ integrin and laminin, suggesting its involvement in the interaction between Schwann cells and the surrounding basal lamina [1]. Therefore, together with the observation that conditional knockout of the mouse gp130 gene caused degeneration of myelin sheath [2], we surmise that IL-6 signaling through the gp130/JAK/STAT pathway may regulate PMP22 expression and thereby contribute to the formation or stabilization of the compact myelin.

Earlier studies have revealed that PMP22 expression is regulated transcriptionally by cyclic AMP [25] and post-transcriptionally by microRNA-29a [27]. The relationship between these regulatory processes and the present results is currently unclear. In DRG neurons, levels of IL-6 mRNA and IL-6 increase rapidly within a day and gradually decreases over 1-2 weeks after transection and elongation of sciatic nerve [8,19,22]. Also, Sheu et al. have shown that phosphorylation of STAT3 in both proximal and distal ends peaks within a day but remains for more than 2 weeks [23]. In contrast, the PMP22 mRNA level declines immediately after nerve injury and then is upregulated after 1 week [24]. Conceivably, the IL-6-signaling through the gp130/JAK/STAT pathway may participate in 
the delayed upregulation of PMP22; however, the initial reduction could not be explained by the same mechanism. More detailed analysis is required to determine the contribution of the IL-6 and gp130/JAK/STAT signaling to the peripheral nerve regeneration.

In conclusion, we have demonstrated that IL-6 can upregulate PMP22 expression through a JAK2-dependent pathway. If this pathway is critical for in vivo myelin synthesis, the recent challenges for pharmacological interventions targeting the gp130-mediated signaling [7] might benefit the treatment of neuropathies associated with abnormal myelin formation. Also, upon Schwann cell transplantation into an injured nerve [21], it would be important to control the gp130/JAK/STAT pathway to ensure proper myelination.

\section{Acknowledgements}

This work was supported in part by grants from the Ministry of Education, Culture,

Science, Sports and Technology of Japan, and from the Center of Excellence (COE) research program of Kanazawa University. 


\section{References}

[1] S. A. Amici, W. A. Dunn Jr., A. J. Murphy, N. C. Adams, N. W. Gale, D. M. Valenzuela, G. D. Yancopoulos, L. Notterpek, Peripheral myelin protein 22 in complex with $\alpha 6 \alpha 4$ integrin, and its absence alters the Schwann cell basal lamina, J. Neurosci. 26 (2006) $1179-1189$.

[2] U. A. K. Betz, W. Bloch, M. van den Broek, K. Yoshida, T. Taga, T. Kishimoto, K. Addicka, K. Rajewsky, W. Müller, Postnatally induced inactivation of gp130 in mice results in neurological, cardiac, hematopoietic, immunological, hepatic, and pulmonary defects, J. Exp. Med. 188 (1998) 1955-1965.

[3] J. G. Boyd, T. Gordon, Neurotrophic factors and their receptors in axonal regeneration and functional recovery after nerve injury, Mol. Neurobiol. 27 (2003) 277-323.

[4] Z.-L. Chen, W.-M. Yu, S. Strickland, Peripheral regeneration, Ann. Rev. Neurosci. 30 (2007) 209-233.

[5] D. T. Dudley, L. Pang, S. J. Decker, A. J. Bridges, A. R. Saltiel, A synthetic inhibitor of the mitogen-activated protein kinase cascade, Proc. Natl. Acad. Sci. U.S.A. 92 (1995) 7686-7689.

[6] M. Ernst, B. J. Jenkins, Acquiring signaling specificity from the cytokine receptor gp130, Trends Genet. 20 (2004) 23-32.

[7] P. Fischer, D. Hilfiker-Kleiner, Role of gp130-mediated signaling pathways in the heart 
and its impact on potential therapeutic aspects, Br. J. Pharmacol. 153 (2008)

S414-S427.

[8] R. A. Gadient, U. H. Otten, Interleukin-6 - a molecule with both beneficial and destructive potentials, Prog. Neurobiol. 52 (1997) 379-390.

[9] B. Garbay, A. M. Heape, F. Sargueil, C. Cassagne, Myelin synthesis in the peripheral nervous system, Prog. Neurobiol. 61 (2000) 267-304.

[10] C. Grothe, K. Heese, C. Meisinger, K. Wewetzer, D. Kunz, P. Cattini, U. Otten, Expression of interleukin-6 and its receptor in the sciatic nerve and cultured Schwann cells: relation to 18-kD fibroblast growth factor-2, Brain Res. 885 (2000) 172-181.

[11] K. Ishihara, T. Hirano, Molecular basis for the cell specificity of cytokine action, Biochim. Biophys. Acta 1592 (2002) 281-296.

[12] K. R. Jessen, R. Mirsky, The origin and development of glial cells in peripheral nerves, Nat. Rev. Neurosci. 6 (2005) 671-682.

[13] R. Lara-Ramírez, E. Segura-Anaya, A. Martínez-Gómez, M. A. R. Dent, Expression of interleukin-6 receptor a in normal and injured rat sciatic nerve, Neuroscience 152 (2008) 601-608.

[14] H. K. Lee, I. A. Seo, D. J. Suh, J. I. Hong, Y. H. Yoo, H. T. Park, Interleukin-6 is required for early induction of glial fibrillary acidic protein in Schwann cells during Wallerian degeneration, J. Neurochem. 108 (2009) 776-786. 
[15] N. Meydan, T. Grunberger, H. Dadi, M. Shahar, E. Arpaia, Z. Lapidot, J. S. Leeder, M. Freedman, A. Cohen, A. Gazit, A. Levitzki, C. M. Roifman, Inhibition of acute lymphoblastic leukaemia by a Jak-2 inhibitor, Nature 379 (1996) 645-648.

[16] T. K. Morrissey, N. Kleitman, B. P. Bunge, Isolation and functional characterization of Schwann cells derived from adult peripheral nerve, J. Neurosci. 11 (1991) 2433-2442.

[17] P. G. Murphy, J. Grondin, M. Altares, P. M. Richardson, Induction of interleukin-6 in axotomized sensory neurons, J. Neurosci. 15 (1995) 5130-5138.

[18] L. Notterpek, G. J. Snipes, E. M. Shooter, Temporal expression pattern of peripheral myelin protein 22 during in vivo and in vitro myelination, Glia 25 (1999) 358-369.

[19] N. Osamura, K. Ikeda, T. Ito, H. Higashida, K. Tomita, S. Yokoyama, Induction of interleukin-6 in dorsal root ganglion neurons after gradual elongation of rat sciatic nerve, Exp. Neurol. 195 (2005) 61-70.

[20] A. Ozaki, A. Nagai, Y. B. Lee, N. H. Myong, S. U. Kim, Expression of cytokine receptors in human Schwann cells, Neuroreport 19 (2008) 31-35.

[21] C. Radtke, Y. Akiyama, K. L. Lankford, P. M. Vogt, D. S. Krause, J. D. Kocsis, Integration of engrafted Schwann cells into injured peripheral nerve: axonal association and nodal formation on regenerated axons, Neurosci. Lett. 387 (2005) $85-89$.

[22] C. Y. Saab, F. Shamaa, M. E. E. Sabban, B. Safieh-Garabedian, S. J. Jabbur, N. E. 
Saadé, Transient increase in cytokines and nerve growth factors in the rat dorsal root ganglia after nerve lesion and peripheral inflammation, J. Neuroimmunol. 208 (2009) 94-103.

[23] J. Y. Sheu, D. J. Kulhanek, F. P. Eckenstein, Differential patterns of ERK and STAT3 phosphorylation after sciatic nerve transaction in the rat, Exp. Neurol. 166 (2000) $392-402$.

[24] G. J. Snipes, U. Suter, A. A. Welcher, E. M. Shooter, Characterization of a novel peripheral nervous system myelin protein (PMP22/SR13), J. Cell Biol. 117 (1992) $225-238$.

[25] U. Suter, PMP 22 gene. In: R. A. Lazzarini (Ed.), Myelin Biology and Disorders, Vol. 1, Elsevier Academic Press, San Diego, 2004, pp. 547-564.

[26] S. W. N. Thompson, J. V. Priestley, A. Southall, gp130 cytokines, leukemia inhibitory factor and interleukin-6, induce neuropeptide expression in intact adult sensory neurons in vivo: time-course, specificity and comparison with sciatic nerve axotomy, Neuroscience 84 (1998) 1247-1255.

[27] J. D. Verrier, P. Lau, L. Hudson, A. K. Murashov, R. Renne, L. Notterpek, Peripheral myelin protein 22 is regulated post-transcriptionally by miRNA-29a. Glia 57 (2009) 1265-1279.

[28] P.-L. Zhang, A. M. Levey, L. Ben-Simchon, S. Haggiag, J. Chebath, M. Revel, 
Induction of neuronal and myelin-related gene expression by IL-6-receptor/IL-6: a study on embryonic dorsal root ganglia cells and isolated Schwann cells, Exp. Neurol. 208 (2007) 285-295.

[29] J. Zhong, I. D. Dietzel, P. Whale, M. Kopf, R. Heumann, Sensory impairments and delayed regeneration of sensory axons in interleukin-6 deficient mice, J. Neurosci. 19 (1999) 4305-4313. 


\section{Figure legends}

Fig. 1. (A) Immunoperoxidase staining of Schwann cells cultured from adult rat sciatic nerve. Cells were stained with anti-S100 antibodies. Note that S100-positive cells are bi- or tri-polar. Scale bar, $40 \mu \mathrm{m}$. (B) Expression of mRNA for IL-6 receptor subunits. Cells cultured without IL-6 were subjected to RT-PCR analysis using primers for IL6-R or gp130 primers as indicated on the left. The amplified products were hybridized with a probe specific to each subunit. The presence $(+)$ or absence $(-)$ of RT is indicated at the top.

Fig. 2. Effects of IL-6 on the mRNA levels of myelin-associated proteins. Schwann cells were stimulated with IL-6 at indicated concentrations. After 12 h, total RNA was extracted, and was then subjected to RT-PCR followed by Southern blot hybridization analysis. (A) Representative autoradiograms for MPZ, MBP, and PMP22 (from top to bottom) are given with that for cyclophilin $(C Y C)$ as a control. (B) Densitometric analysis of autoradiograms as shown in (A). A bar graph represents band intensities normalized to those for CYC. Each bar represents the average \pm SEM of independent experiments $(n=3$ for MPZ and MBP, 8 for PMP22. Fisher's post hoc $t$ test was used for comparison. *, $p<0.05$; compared with the control.

Fig. 3. Effects of JAK2 and MAPKK inhibitors on IL-6 induced PMP22 expression. (A) 
Cultured Schwann cells were pretreated with $50 \mu \mathrm{M}$ AG490 for 16h or $25 \mu \mathrm{M}$ PD098059 for $30 \mathrm{~min}$, and then stimulated with $0.5 \mu \mathrm{g} / \mathrm{ml}$ recombinant IL-6. After $12 \mathrm{~h}$, total RNA was extracted and subjected to RT-PCR combined with Southern blot hybridization.

Representative autoradiograms for PMP22 and cyclophilin $(C Y C)$ are given. Cells treated with AG490 or PD098059 were analyzed in duplicate. (B) Densitometric analysis of the band intensities for PMP22. Band intensities were normalized to those for CYC. Each bar represents the average \pm SEM of 5 independent experiments. ${ }^{*}, p<0.05 ; N S$, not significant.

Fig. 4. Immunoperoxidase staining of Schwann cells treated with IL-6. Cells were cultured in the absence (A, C, and E) or presence (B, D, and F) of IL-6 $(0.5 \mu \mathrm{g} / \mathrm{ml})$ for $72 \mathrm{~h}$, and were immunostained for PMP22 (A, B), pJAK2 (C, D), and pSTAT3 (E, F). Staining of A, C, and E was performed in parallel with that of $\mathrm{B}, \mathrm{D}$, and $\mathrm{F}$, respectively, under the same conditions. Scale bar, $50 \mu \mathrm{m}$. 
Figure
Click here to download high resolution image

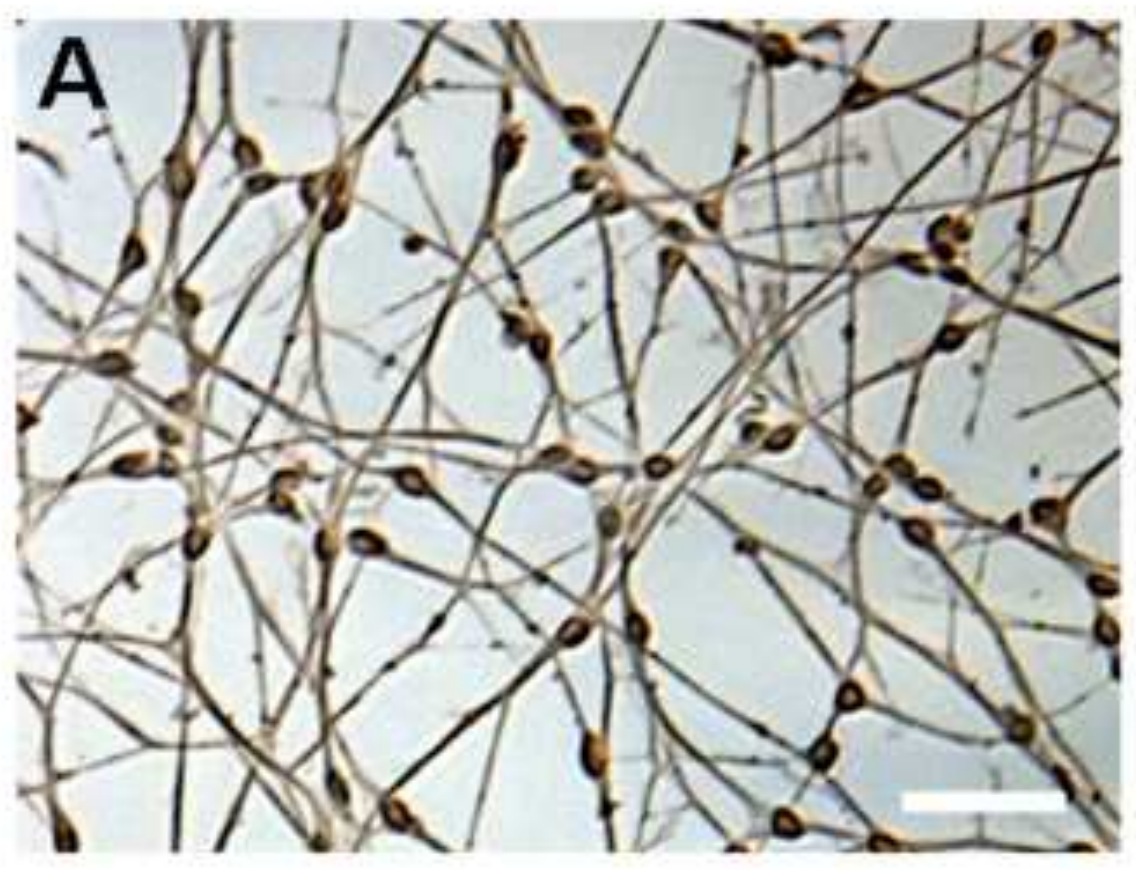

B

RT

$+$

IL-6 R

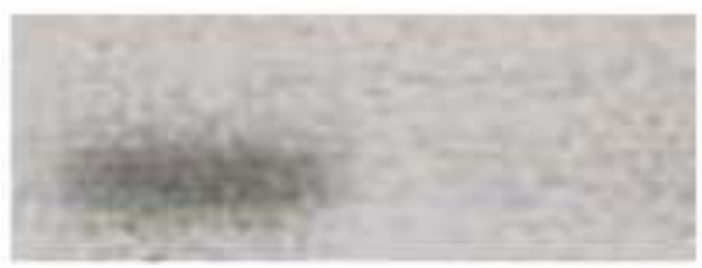

gp130

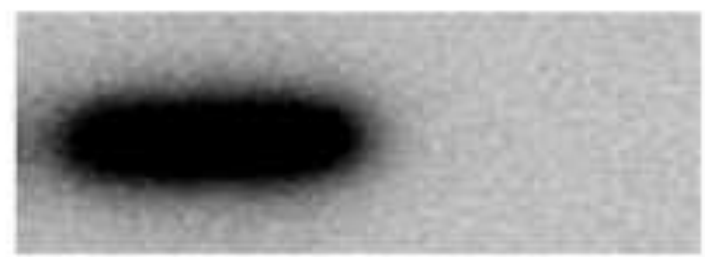


Figure

Click here to download high resolution image
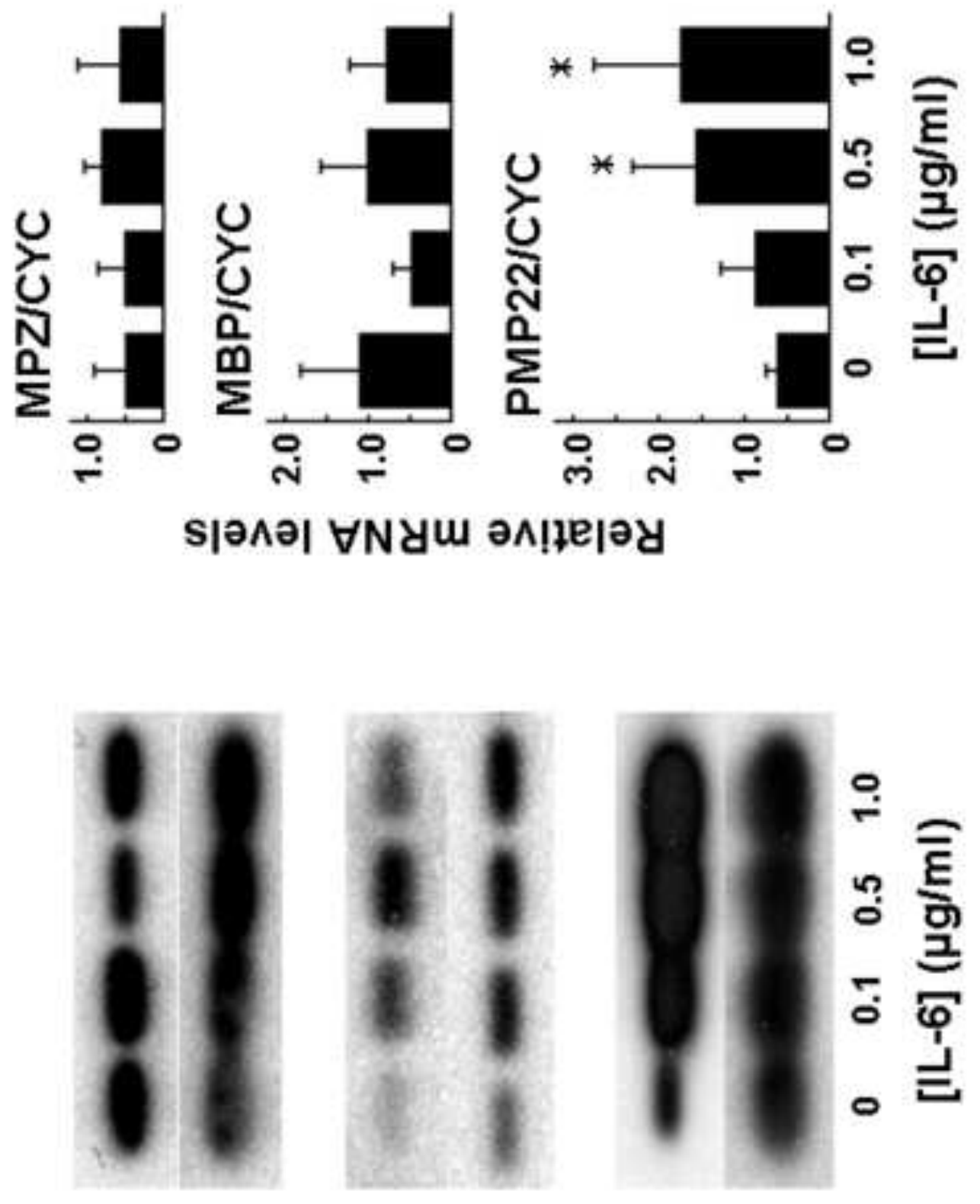

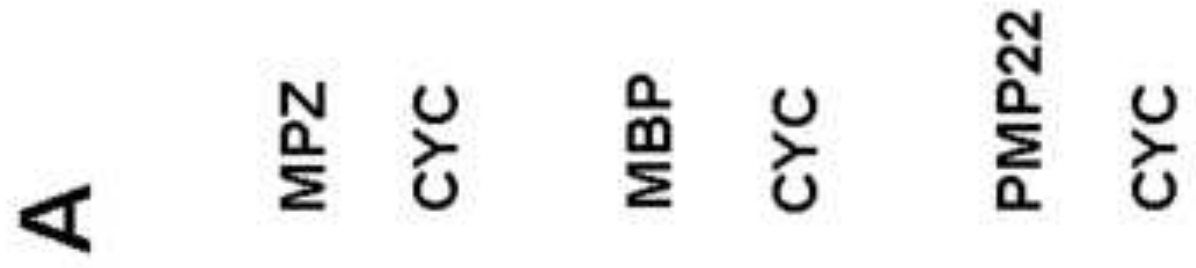


Figure

Click here to download high resolution image

A

$\begin{array}{lllllll}\mathrm{IL}-6 & - & + & + & + & + & + \\ \mathrm{AG} 490 & - & - & + & + & - & - \\ \mathrm{PD} 098059 & - & - & - & - & + & +\end{array}$
PMP22 CYC

B

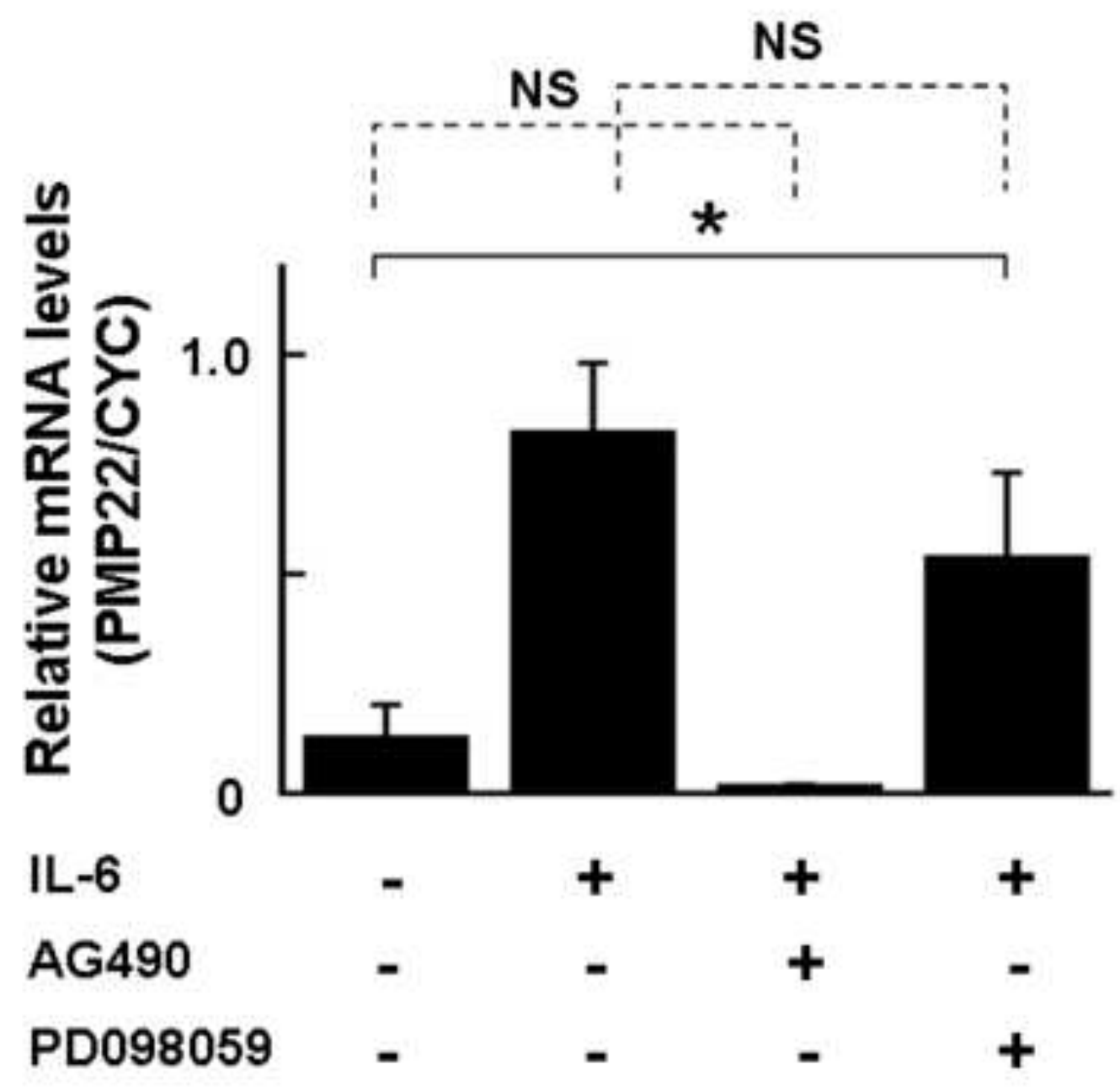


Click here to download high resolution image
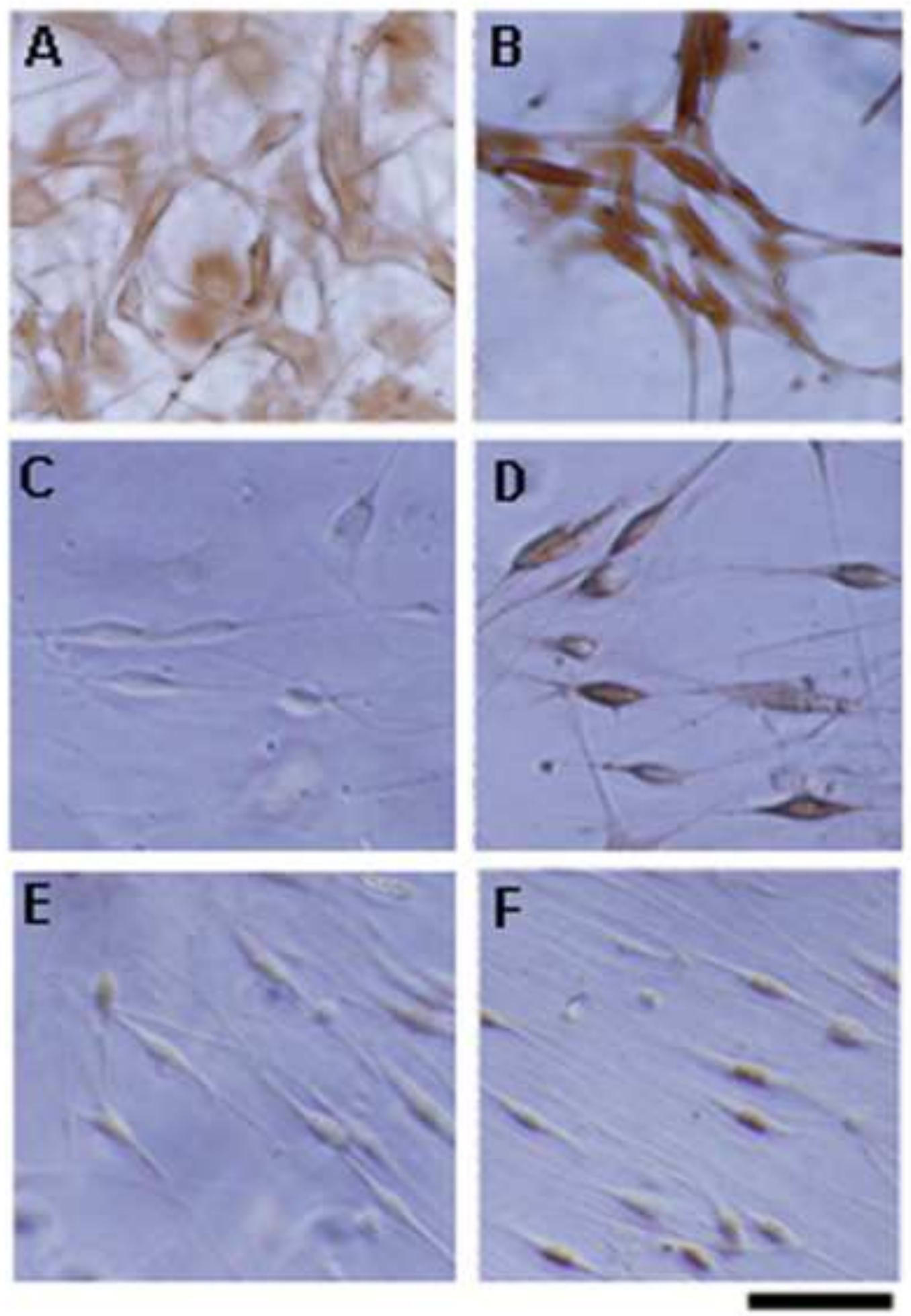
Table 1

Primer sequences for RT-PCR

\begin{tabular}{|c|c|c|c|}
\hline & Sequence $\left(5^{\prime}-3^{\prime}\right)$ & $\begin{array}{l}\text { Annealing } \\
\text { temperature }\left({ }^{\circ} \mathrm{C}\right)\end{array}$ & $\begin{array}{l}\text { Product } \\
\text { length (bp) }\end{array}$ \\
\hline \multirow[t]{2}{*}{ IL-6R $\alpha$} & F: TGGTGCAGCCGGATCCACCTGCCA & 69 & 435 \\
\hline & R: CTGGGGCGAGGACACTCGTTGCTT & & \\
\hline \multirow[t]{2}{*}{ gp130 } & F: GCCCTTGGGAATGTCTCCTCAGAG & 61 & 451 \\
\hline & R: TCTTCCATATGAGCCGTGCAGACC & & \\
\hline \multirow[t]{2}{*}{ MPZ } & F: CCTTGCCCCTACCCCAGCTA & 67 & 782 \\
\hline & R: CCCGGCCCGCTAACCGCTAT & & \\
\hline \multirow[t]{2}{*}{ MBP } & F: CTTCCGAAGGCCTGGATGTG & 64 & 407 \\
\hline & R: TCAGCGTCTTGCCATGGGAG & & \\
\hline \multirow[t]{2}{*}{ PMP22 } & F: CCCAACTCCCAGCCACCATG & 65 & 500 \\
\hline & R: TCATTCGCGTTTCCGCAGGATC & & \\
\hline \multirow[t]{2}{*}{ CYC } & F: TTGGGTCGCGTCTGCTTCGA & 63 & 240 \\
\hline & R: GCCAGGACCTGTATGCTTCA & & \\
\hline
\end{tabular}

$\mathrm{F}$ and $\mathrm{R}$ refer to forward and reverse primers. 